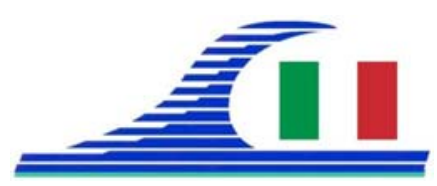

Conférence Méditerranéenne Côtière et Maritime

EDITION 3, FERRARA, ITALIA (2015)

Coastal and Maritime Mediterranean Conference

Disponible en ligne - http://www.paralia.fr - Available online

\title{
A new beach nourishment strategy for Bibione littoral
}

\author{
Massimo TONDELLO $^{1,2}$
}

1. Hydrosoil S.r.l., Via Panà 56/A, 35027 Noventa Padovana (PD), Italy. massimo.tondello@hydrosoil.com

2. Centro Dipartimentale Sealine, Dipartimento di Architettura, Università di Ferrara

Via della Ghiara 36, 44121 Ferrara, Italy.

massimo.tondello@unife.it

\begin{abstract}
:
Erosion is striking hard almost all sandy beaches in the Northern Adriatic Sea; among these beaches, the Bibione littoral plays a very important role because of its environmental and socio-economical potential. More of 6 million tourists spend their holidays in Bibione and large parts of the littoral are included in Natura 2000 sites.

It is therefore evident that coastal protection cannot be managed using temporary or local solutions, but requires a comprehensive strategy to provide effective solutions in the medium term and full respect of the environment. With a maximum shoreline retreat rate of $10 \mathrm{~m} / \mathrm{y}$, the beach can be classified in a very critical condition; despite this, the net sediment balance in the nearshore (i.e. emerged and submerged beach) is close to equilibrium (FONTOLAN, 2014). The sediment management option has been therefore considered as a viable solution for coastal protection; this solution also allows for the minimization of the environmental impact and the preservation of the environmental and touristic value of the area. On this basis, a soft solution has been developed, consisting in the periodic beach nourishment via a stable pipeline which brings the sand dredged at the Tagliamento river mouth to the most critical areas downstream. An extensive monitoring program has been also undergone, together with the design of the pipeline, in order to find all available nearshore deposits and to determine the erosion trend for managing beach nourishment in the next future.

The procedure for approval and permitting of the works has been itself a "new design", being the specific regulation the result of a thoroughly debate between scientists, stakeholders and local administrations. Moreover, financing of design and works is a public/private joint venture, most likely the first in Italy.

The paper presents all the surveys, investigations and design activities performed in the framework of the Bibione littoral coastal protection plan.
\end{abstract}

Keywords: Coastal engineering, ICZM, Beach, Tourism, Sediments, Governance, Dredging, Nourishment, Maintenance, Stakeholders, Pipeline. 
Côtes méditerranéennes menacées :

Risques et défis dans le contexte du changement climatique

\section{Introduction}

Bibione littoral is located in the western lobe of Tagliamento river delta (see Fig. 1); the delta was a river dominated one (ZUNICA, 1971), protruding from a relatively straight coastline, but, due to the reduced river sediment supply, longshore sediment transport is flattening the delta cusp, thus producing erosion and accretion phenomena in its surroundings. Erosion is concentrated in the delta cusp, and turns progressively into accretion some miles away from the river mouth (RAMELLA et al., 2004). The dramatic changes in littoral landscape are shown in Figure 2, where the littoral lagoon behind the beach is almost disappeared, filled by the overwash of the beach sand.

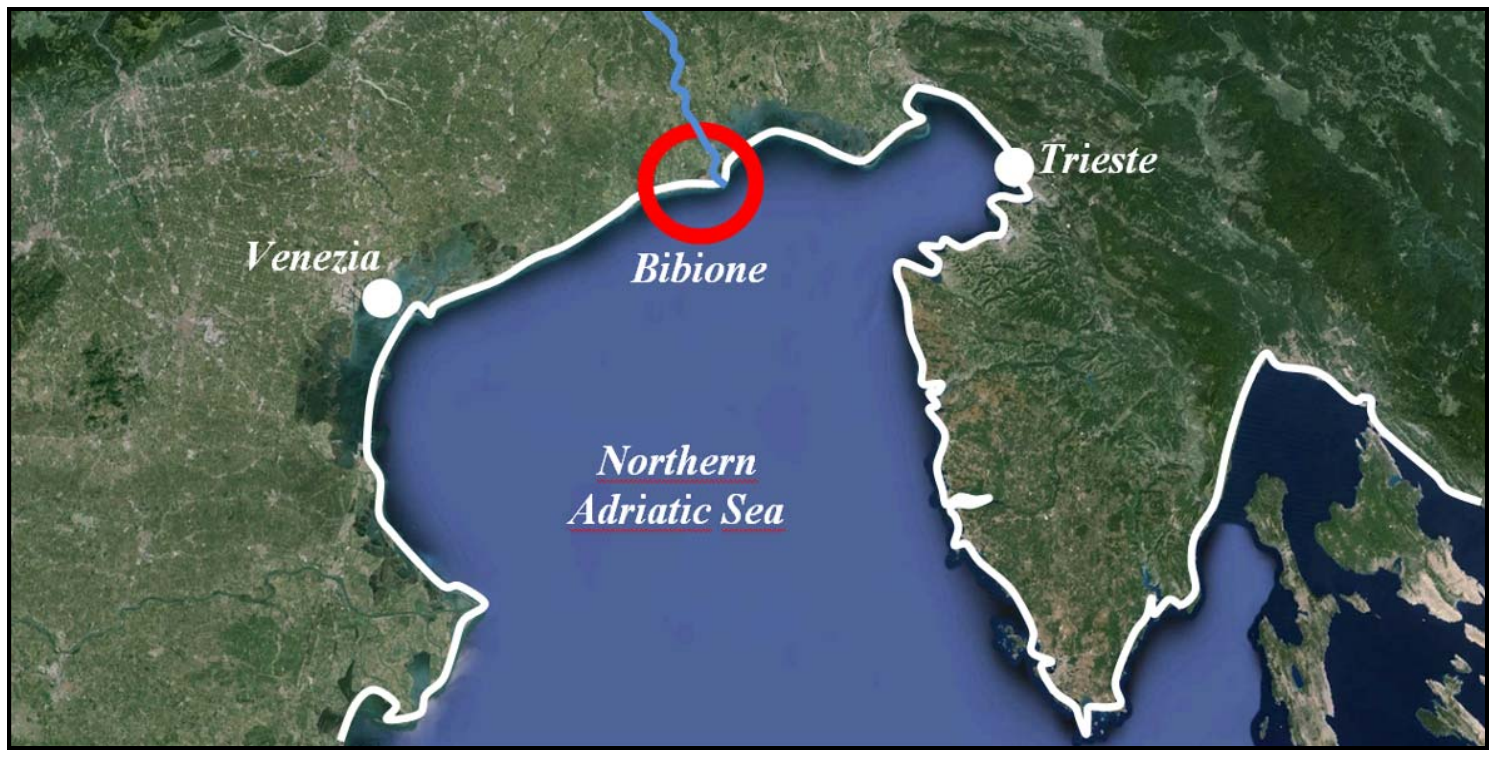

Figure 1. Area of interest.
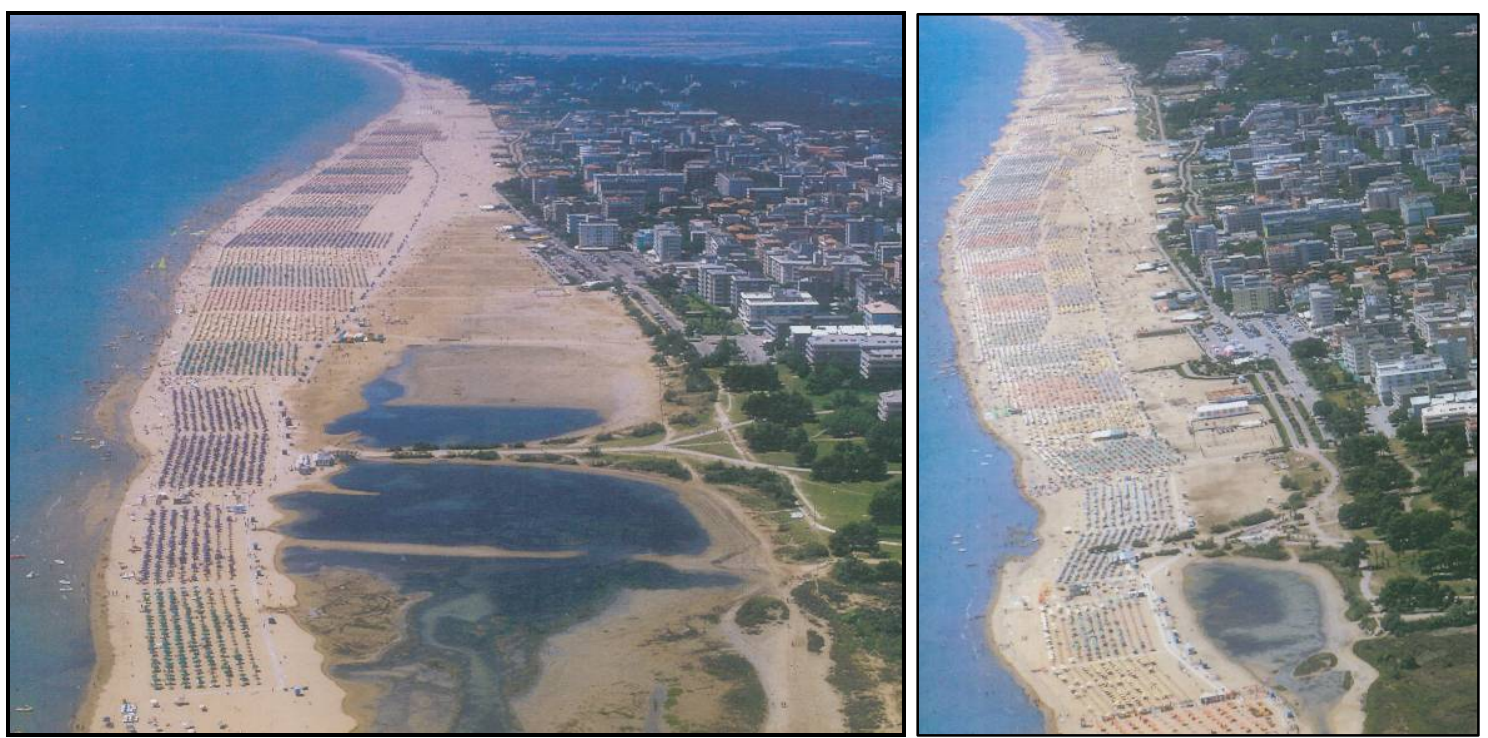

Figure 2. Evolution of Bibione littoral from 1990 (left) to 2013 (right). 
Mediterranean coasts at threat:

Hazards and challenges in the context of climate variability

\section{Littoral dynamics}

The three main factors governing the shoreline evolution are the sediment supply from the river, the longshore sediment transport (see numerical modelling results in Fig. 3) and the presence of breakwaters (later evolved into a seawall because of tombolo formations, see black dotted line in Fig. 3) in the western side of the river mouth.

The sediment supply from the river is reducing because of the construction of dikes and embankments along the river; nevertheless, about $100,000 \mathrm{~m}^{3}$ of sediments reaches the sea every year. This volume is not enough to maintain the shape of the delta cusp, and a progressive erosion of the cusp took place since the $80 \mathrm{~s}$; in order to prevent this erosion, a series of breakwaters have been built, and later enlarged, in the last 20 years.

The breakwaters have been very effective in preventing local erosion, but shifted the problem downdrift: the downdrift beaches, in fact, began to suffer not only because of the reduction in river sediment supply, but also because the remaining sediment transport changed its course, bypassing part of the littoral or depositing too far from the shore to nourish the beach (see Fig. 4).

Periodic beach nourishment and other soft (or "light", such as wood groins) interventions could not cope with the erosion trend; therefore, a thoroughly survey and study program was began by the public and private subjects (Region authority, Municipality, Stakeholders), in order to develop an ICZM strategy.
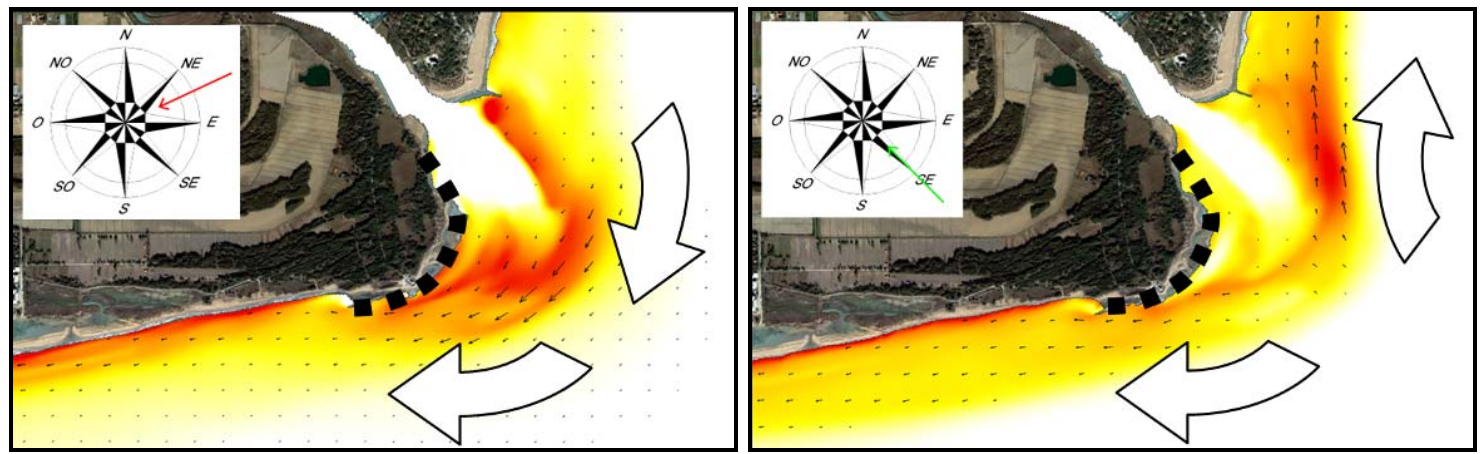

Figure 3. Sediment transport during typical Bora (left) and Sirocco (right) storms.

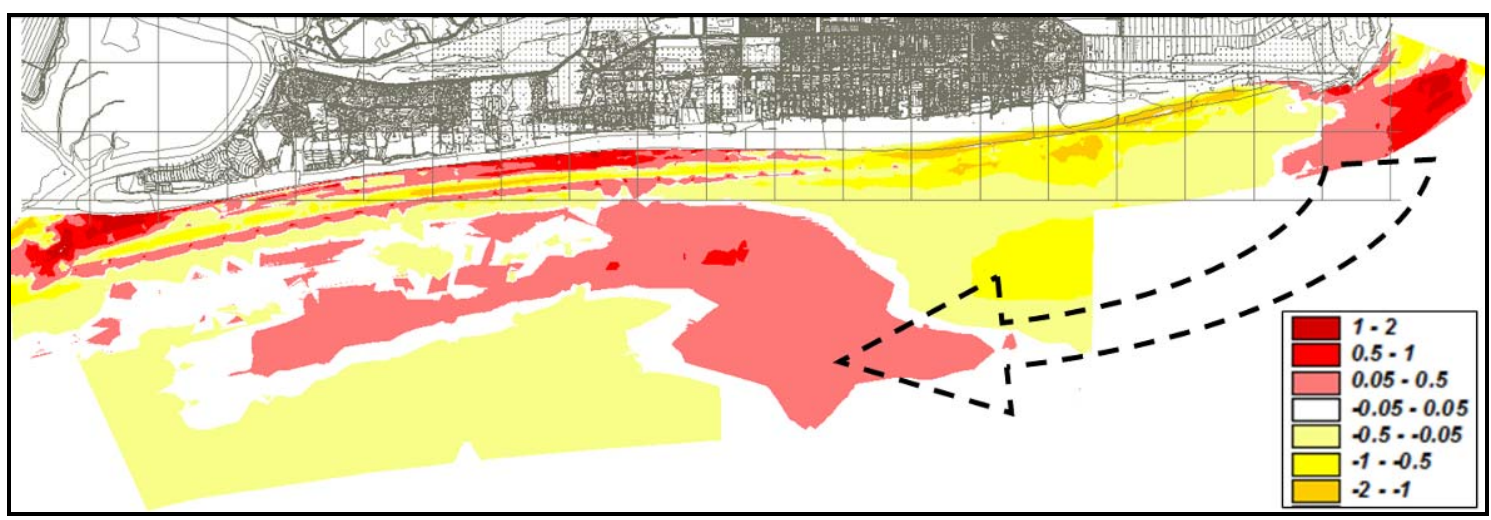

Figure 4. Erosion/deposition patterns (m) in the period 2014/2003. 
Côtes méditerranéennes menacées :

Risques et défis dans le contexte du changement climatique

\section{Coastal protection strategy}

The coastal protection strategy, as far as it is developed at present, aims at defining a procedure for monitoring the beach and the sediment resources, developing design solutions and providing the necessary funding for interventions. Though still at a beginning stage (monitoring began in 2014 and studies are still on course), a detailed agreement among the public and private companies has been subscribed and a first action plan shared and financed. The first action plan aims at bringing river sediment supply in the deficit areas: sediments will be taken from the river mouth, and from the deposition areas in front of the mouth, using a suction dredger discharging through a floating pipeline into a $400 \mathrm{~mm}$ buried pipeline, $2700 \mathrm{~m}$ long (see Fig. 5). A booster station provides the additional power required for the mix to reach the end of the pipeline. A series of outflow devices are available for supplying the sand according to the needs. Future action plans will likely deal with the recovery of sand from the western parts of the littoral, where shoreline accretion and relevant depositional phenomena in shallow water are occurring.

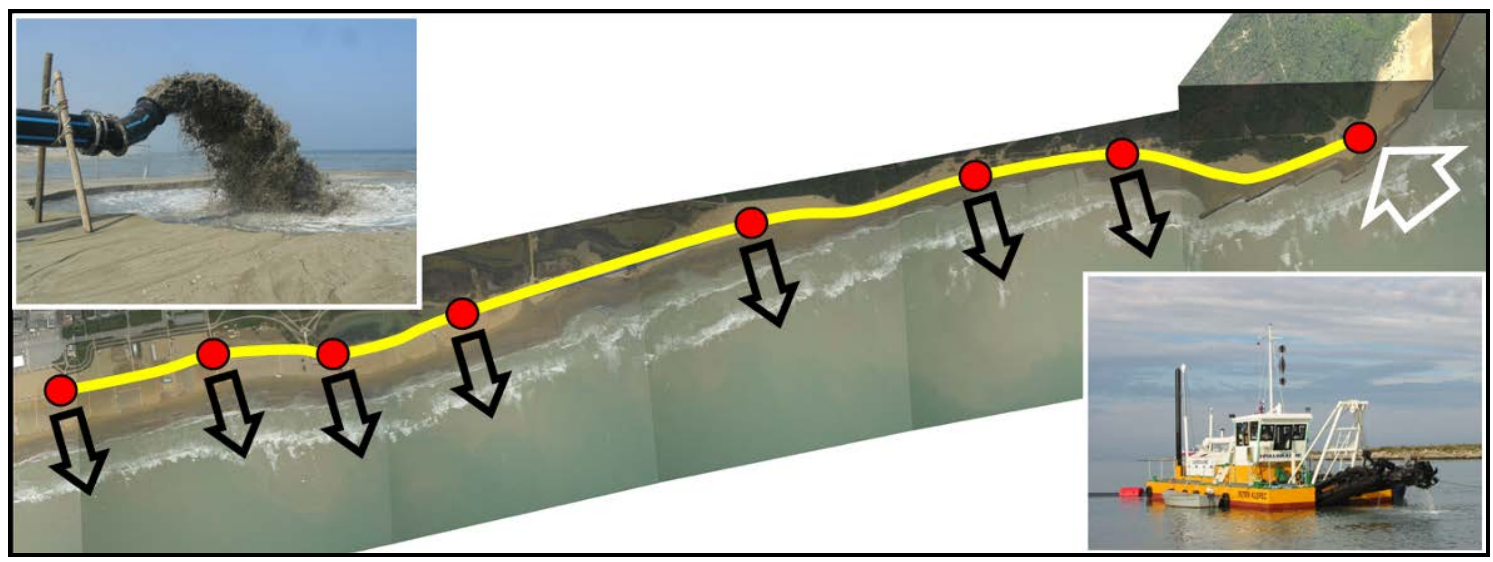

Figure 5. Sand pipeline (yellow) and in/out points (red).

\section{References}

FONTOLAN G. (2014). Geodatabase gestionale delle coste venete, Shape EU Project WP5 action 5.4.1. URL :

http://sistemavenezia.regione.veneto.it/sites/default/files/documents/08_Shape/RelazioneGCV-rev-ott2015_0.pdf

RAMELLA R., VIEZZOLI D., GORDINI E., CODIGLIA R., ROMEO R., DEPONTE M. (2004). Indagini meteo-oceanografiche, batimetriche, sedimentologiche $e$ morfologiche finalizzate allo studio dei fenomeni di dinamica costiera lungo i litorali di Lignano Sabbiadoro e Bibione. OGS, Trieste.

ZUNICA M. (1971). Le spiagge del Veneto. Centro di Studi per la Geografia Fisica, Univ. Di Padova, Tipografia Antoniana, Padova, 144 p. 